\title{
Fieldwork and Research Impact on Learning of Disaster Risk Reduction
}

\author{
Ratih Puspita Dewi \\ Department of Geography Education, Universitas Muhammadiyah Surakarta, Central Java, Indonesia
}

Received January 6, 2020 ; Revised June 18, 2020; Accepted June 22, 2020

Copyright (C2020 by authors, all rights reserved. Authors agree that this article remains permanently open access under the terms of the Creative Commons Attribution License 4.0 International License

\begin{abstract}
Fieldwork has been widely known to be important in Geography and other disciplines. Fieldwork was described as an outside activity where students can see and hear the geography phenomena in the field. It was also believed that fieldwork was an essential way to gain a better understanding of geographical objects. Some previous research had shown the advantages of fieldwork for students. Combining fieldwork and research was possible to gain students' understanding of disaster risk reduction in the school community especially in the disaster-prone areas. This research aimed to know the effect of fieldwork and research on undergraduate geography education' students understanding of disaster risk reduction in the school community. Students engaged in field work and research activities in the southern part of Klaten Regency Central Java Indonesia, which is vulnerable to various disasters such as earthquakes, floods and landslides. The students were evaluated before and after fieldwork using questionnaires. The result showed that fieldwork and research improved students' understanding of disaster risk reduction.
\end{abstract}

Keywords Fieldwork, Research, Disaster Risk Reduction, Higher Education

\section{Introduction}

Fieldwork is one of the most powerful, central and important teaching and learning methods in geography. $[1][2][3][4][5][6][7][8][9]$. Fieldwork was interpreted to be a way of study where the location takes place outside of the classroom [10]. It supports geographers to gain a better understanding of what they thought and what it looks like in the real world [1]. This is a method which geographers seek to learn by doing the real thing [3]. Fieldwork provides an experience in which cognitive and affective domains strengthen each other [8] In addition, the acquisition of geographers' qualities and the ability to think spatially is significant as one factor affects the success of the workplace. [11]. The learning situation is created directly by observation in the field. Students can learn the connection between a feature or pattern and how they relate to the theory they have learned in class, so that students can see and hear directly about geographical phenomena. [12].

Other variations of fieldwork need to be conducted to enhance the learning experience through field courses [13]. Combining fieldwork and research enables students to observe, collect data, apply methods and analyze data.. In addition, it creates atmospheres in which students improve their skills to work in peer-to-peer groups, recognize the real issue and gain experience in fields that may differ from what they think. On the other hand, as a pre-service teacher in Geography, students need to learn how school community activities run. Disaster risk reduction is one issue that gains popularity recently. It is because in several years disasters occur in several regions for example earthquakes in Yogyakarta and South part of Klaten Regency in Central Java Indonesia in 2006. All schools community have to improve their understanding of disaster risk reduction and school' disaster management because community-based disaster mitigation makes vulnerability decrease [14]. Thus, this combination of fieldwork and research could be effective in enhancing geography education for students on disaster risk reduction in the school community.. However, the evaluation of this method needs to be conducted as stated that evaluation for fieldwork is needed to be done regularly [2]. Further investigation about the effectiveness of fieldwork in improving students learning need to be conducted [15]

\section{Materials and Methods}

\section{Fieldwork and research design}

This fieldwork and research were organized by The 
Department of Geography Education in Universitas Muhammadiyah Surakarta and this activity was integrated within the curriculum. Fieldwork and research become one of the required activities in Geography Education. Fieldwork was done systematically and by specifying fieldwork outcomes. The fieldwork outcomes were articles focused on schools' disaster management and should be published in the journal or proceeding. This fieldwork was supported by four geography education' lecturers. It was important for students to discuss their research plan with their lecturers who have had experienced in fieldwork [16]. In this field work, students were expected to work in a small group of 3-5 students in some schools in the southern part of Klaten Regency Central Java Indonesia. Students design their own research project by considering some criteria, for instance, schools' location of diaster risk and school status (such as school-based disaster preparedness). The steps were conducted through formulating research questions, the methodology, and the creation of the instruments. So, the fieldwork was undertaken on their own research. Fieldwork was conducted in two days. In the first-day students went to schools to collect the data they needed and investigated what they wanted to know about disaster management in schools. In the second day, students were supposed to continue collecting data, observing school conditions, and presenting their temporary results. It was essential that student had good contact to obtain permission from the school to carry out this fieldwork and research work. [16], The design was nearly similar to Fuller et al (2014) [17]. In the field work, students and staff are doing the same research projects. Students were conducting research by themselves supervised by the staff.

\section{Evaluation}

The aim of this research was to know the impact of fieldwork and research on geography education students' understanding of disaster risk reduction in the schools' community. In order to achieve this aim, a questionnaire was administered to collect the data. It comprised of open and closed questions. The students ought to fill out the questionnaire before and after the program. The questions contained four parameters adopted from Triyono (2013) [18] in the handbook of school-based disaster preparedness implementation published by Indonesia Institue of Sciences. The parameters were (1) policy of disaster preparedness, (2) plan of emergency response, (3) early warning system, and (4) resources mobilization. However, in this research, some questions were modified and deleted because of the efficiency and correlation to this research. The first parameter related to students' understanding of school policy to promote schools' preparedness toward disaster. The second component investigated whether students can improve their ability to perceive the information about schools' plans and actions to respond to an emergency condition to reduce the disaster risk. The third element was intended to determine students' consideration of schools' community involvement in disaster early warning systems. The fourth parameter looked at whether students understand the effort of school to mobilize their resources effectively. This research was supposed to know students' understanding of those four parameters and finally to know how students' understanding of disaster risk reduction in school community enhance before and after the fieldwork. Each question was answered by a three-point scale which yes $=2$, no $=1$, and don't know $=0$. The test score of the participants was obtained and each component was analyzed using statistical analysis. The statistic analysis was paired sample t-test to determine the differences between pretest score and posttest score for each student. Statistical significant was accepted if significant 2 tailed $<0.05$.

\section{Result}

\section{The impact of combine fieldwork and research}

Students were supposed to observe the school community before the beginning of the fieldwork to request permission from the schools and finding the main issue that schools face especially in disaster risk reduction. After that, they should decide the research title, find the appropriate method, and arrange the instrument to collect data. The student research topic was developed in the following steps: (1) Analysis of elementary students' knowledge about earthquake, (2) Adaptive capacity and resiliency in the disaster risk reduction of senior high school students, (3) The role of extracurricular in the disaster risk reduction among senior high school students, (4) Smart SOP in the earthquake's disaster risk reduction, (5) Knowledge of flood's disaster risk reduction effort in senior high school, (6) The influence of disaster education to earthquake preparedness behavior di junior high school, (7) Analysis of vulnerability and capacity in junior high school, (8) Response to earthquake disaster mitigation in junior high school, (9) Identification of senior high school readiness to implemented school-based disaster preparedness in the disaster-prone area, (10) Analysis of earthquake preparedness in junior high school, (11) Disaster risk reduction for flood in junior high school, (12) Study of school facility to support disaster risk reduction in junior high school, (13) Self Efficacy in disaster preparedness in junior high school, (14) Knowledge and behavior of junior high school students to face flood and earthquake, (15) The readiness of teachers to teach disaster in disaster-prone area, (16) Elementary adaptation of students to face flood.

From the students' research title, it can be known that the topic was varied. However, most of them were in the social aspects. It can be seen that out of 16 topics, 13 were pure 
social topic, 2 combined social and physical topics, and only 1 physical topic. It was known that there were two types of disaster mitigation, i.e. structural mitigation and non-structural mitigation. From the research topic it can be concluded that students interested in finding out how non-structural mitigation in the school community, and even though the aim was almost similar, the research had different ideas the students want to bring about. The research focus on (1) knowledge and attitudes toward disaster, (2) vulnerability, capacity, and resiliency of school community, (3) school community preparedness, (4) school community readiness of disaster, (5) the role of social and physical capital in disaster risk reduction.

Table 1. Descriptive statistic for mean score per questions for all students

\begin{tabular}{|c|c|c|c|c|c|}
\hline & N & Mean & $\begin{array}{c}\text { Standard } \\
\text { Deviation }\end{array}$ & Minimum & Maximum \\
\hline $\begin{array}{c}\text { Pre } \\
\text { fieldwork }\end{array}$ & 36 & 0.7 & 0.26 & 0.37 & 1.65 \\
\hline $\begin{array}{c}\text { Post } \\
\text { fieldwork }\end{array}$ & 36 & 1.44 & 0.28 & 1.00 & 1.93 \\
\hline
\end{tabular}

Student knowledge of disaster management in the school community was evaluated using questionnaires comprised of 36 questions where the students should fill up the questionnaire before and after fieldwork. Table 1 shows that there were striking differences which mean the value of pretest and posttest had a prominent increase from 0.7 to 1.44. The minimum climbed to 1.00 from 0.37 , and the maximum step up to 1.93 from 1.65 (the lowest possible score was 1 and the highest 3 )

\section{The policy of disaster preparedness}

Table 2 showed that pretest and posttest value for all items in policy and disaster preparedness were increased. It was indicated that there were significant increases in student knowledge (sig 2 tailed $<0.05$ ) before and after fieldwork and research. The significant differences were in the role of disaster group and in the school program related to disaster besides the program from the government. The policy of disaster preparedness could be one action in preparing preparedness among the school community member. Following one of five actions, The Hyogo Framework for Action, they used knowledge, innovation, and education to build safety and resilience culture [19]. Furthermore, disaster policy could build a strong institution to implement disaster risk reduction programs through the school community. Regarding the importance of disaster policy, it was prominent that students through fieldwork and research improved their knowledge of disaster policy in school. Based on the mean value, students consider that every school must have a disaster policy only because they do not know whether the school has a policy or a program.

Table 2. Analysis of the policy of disaster preparedness' knowledge

\begin{tabular}{|c|c|c|c|c|c|}
\hline \multirow{2}{*}{ Item } & \multicolumn{2}{|c|}{ Pre fieldwork } & \multicolumn{2}{c|}{ Post fieldwork } & \multirow{2}{*}{$\begin{array}{c}\text { Significance } \\
\text { (2-tailed) }\end{array}$} \\
\cline { 2 - 5 } & Mean & SD & Mean & SD & 0.14 \\
\hline Every school has disaster mitigation policy & 1.26 & 0.88 & 1.91 & 0.50 & 0.05 \\
\hline Headmaster/teacher/staff know the disaster policy & 1.02 & 0.94 & 1.86 & 0.64 & $\mathbf{0 . 0 0}$ \\
\hline $\begin{array}{l}\text { School has/create policy/program regardless of } \\
\text { government policy }\end{array}$ & $\mathbf{0 . 6 3}$ & $\mathbf{0 . 9 0}$ & $\mathbf{1 . 5 8}$ & $\mathbf{0 . 7 0}$ & $\mathbf{0 . 7 9}$ \\
\hline $\begin{array}{l}\text { If school has disaster group, it has runs as its role and } \\
\text { function }\end{array}$ & $\mathbf{0 . 7 0}$ & $\mathbf{0 . 9 1}$ & $\mathbf{1 . 7 0}$ & $\mathbf{0 . 7 9}$ \\
\hline
\end{tabular}

Table 3. Analysis of plans of emergency response

\begin{tabular}{|c|c|c|c|c|c|}
\hline \multirow{2}{*}{ Item } & \multicolumn{2}{|c|}{ Pre fieldwork } & \multicolumn{2}{|c|}{ Post fieldwork } & Significance \\
\cline { 2 - 6 } & Mean & SD & Mean & SD & -tailed) \\
\hline Schools have back up/copy important document in safe place from disaster & 1.65 & 0.48 & 1.70 & 0.51 & 0.24 \\
\hline School has agreement about evacuation place/shelter & $\mathbf{0 . 6 5}$ & $\mathbf{0 . 9 9}$ & $\mathbf{1 . 4 0}$ & $\mathbf{0 . 8 1}$ & $\mathbf{0 . 0 4}$ \\
\hline School has map and evacuation route & 0.81 & 1.00 & 1.53 & 0.79 & 0.39 \\
\hline School provide tools and equipment for evacuation & $\mathbf{0 . 6 5}$ & $\mathbf{0 . 8 7}$ & $\mathbf{1 . 4 2}$ & $\mathbf{0 . 6 2}$ & $\mathbf{0 . 0 4}$ \\
\hline School held disaster simulation/training & $\mathbf{0 . 4 9}$ & $\mathbf{0 . 8 8}$ & $\mathbf{1 . 1 4}$ & $\mathbf{0 . 7 2}$ & $\mathbf{0 . 0 4}$ \\
\hline School provide first aid box and essential drugs & $\mathbf{0 . 4 4}$ & $\mathbf{0 . 8 2}$ & $\mathbf{1 . 4 4}$ & $\mathbf{0 . 6 6}$ & $\mathbf{0 . 0 0}$ \\
\hline School prepared school health post & $\mathbf{0 . 9 8}$ & $\mathbf{0 . 9 9}$ & $\mathbf{1 . 9 3}$ & $\mathbf{0 . 4 4}$ & $\mathbf{0 . 0 0}$ \\
\hline School activating little doctor and red cross teen & 0.93 & 0.97 & 1.70 & 0.68 & 0.27 \\
\hline School held first aid training & 0.65 & 0.96 & 1.40 & 0.69 & 0.13 \\
\hline School provide first aid SOP & 0.63 & 0.97 & 1.40 & 0.72 & 0.12 \\
\hline School has fixed evacuation procedure & 0.74 & 0.98 & 1.16 & 0.85 & 0.27 \\
\hline Fixed evacuation procedure have been tested in a disaster simulation & $\mathbf{0 . 4 0}$ & $\mathbf{0 . 7 8}$ & $\mathbf{1 . 1 2}$ & $\mathbf{0 . 7 7}$ & $\mathbf{0 . 0 4}$ \\
\hline If the school has a disaster group it has runs match to the fixed procedure & 0.42 & 0.85 & 1.09 & 0.82 & 0.18 \\
\hline
\end{tabular}




\section{Plan of emergency response}

In the plan of emergency response, some indicators tabulated in Table 3 were $>0.5$ so it can be concluded that there were no significant differences in how school save the important document (0.24) and fixed evacuation procedures owned by the schools. But, it can be known that other items were changing significantly $(<0.5)$. The emergency response was related to resilience [20]. Creating a resilience community could prevent greater disaster impact to the community member. Unfortunately, it was still found as for uneducated and untrained volunteers in disaster emergency response [21], to avoid an unexpected case in school emergency response, preservice teachers had to improve their information about these matter as suggested that it was crucial that disaster education was not only related to the schools' disciple but also should be disseminated among families and society[22]. Even though the mean scores increased 6 of 13 items, the effort to advance students' emergency response capability needed to be conducted. Further studies could be focused in this issue.

\section{Early warning system}

Table 4 shows the analysis of the early warning system. There were four items where sig values $>0.5$. They were test in disaster warning system, the school' fixed procedure of the warning' sound and maintain equipment and whether there was a staff group at school to be used for disaster preparedness. Other items show significant increase. This finding was nearly similar to the analysis for an emergency response. There were some parameters that students could not develop during fieldwork and research which was related to the fixed procedure that schools have evacuation procedures to maintain the equipment to face disaster. Students need to increase their knowledge about early warning system' equipment as tools to disseminate the disaster information to all school communities as its importance to reduce disaster victims. In fact, in this parameter students gain the highest understanding for 9 of 13 elements.

Table 4. Analysis of the early warning system

\begin{tabular}{|c|c|c|c|c|c|}
\hline \multirow{2}{*}{ Item } & \multicolumn{2}{|c|}{ Pre fieldwork } & \multicolumn{2}{|c|}{ Post fieldwork } & \multirow{2}{*}{$\begin{array}{c}\text { Significance } \\
\text { (2-tailed) }\end{array}$} \\
\hline & Mean & SD & Mean & SD & \\
\hline School gets access to the information about warning system for disaster & 0.37 & 0.82 & 1.14 & 0.89 & 0.00 \\
\hline School owns the equipment to disseminate disaster's warning system & 0.98 & 0.99 & 1.88 & 0.53 & 0.01 \\
\hline School get information if warning for disaster is canceled & 0.86 & 1.00 & 1.84 & 0.55 & 0.00 \\
\hline School get information about safe condition in disaster & 0.60 & 0.95 & 1.37 & 0.86 & 0.02 \\
\hline School has plan/step response to disaster's warning & 0.70 & 0.97 & 1.53 & 0.85 & 0.01 \\
\hline Warning system for disaster have been socialized to school's community & 0.70 & 0.97 & 1.84 & 0.59 & 0.00 \\
\hline School held disaster's warning system simulation & 0.60 & 0.92 & 1.70 & 0.71 & 0.00 \\
\hline School has agreement sign/sound for disasters' warning system & 0.42 & 0.82 & 1.53 & 0.63 & 0.00 \\
\hline There has warning sign for different type of disaster & 0.56 & 0.93 & 1.58 & 0.79 & 0.00 \\
\hline School has conducted a test on disaster' warning system & 0.53 & 0.91 & 1.19 & 0.78 & 0.19 \\
\hline School has fixed procedure to socialized sign/sound for disaster' warning & 0.42 & 0.82 & 1.07 & 0.78 & 0.07 \\
\hline School has fixed procedure to maintain equipment for facing disaster & 0.60 & 0.89 & 1.21 & 0.79 & 0.57 \\
\hline There are staff/group used for disaster preparedness & 0,67 & 0,95 & 1.33 & 0.79 & 0.62 \\
\hline
\end{tabular}

Table 5. Analysis for resources mobilization

\begin{tabular}{|c|c|c|c|c|c|}
\hline \multirow{2}{*}{ Item } & \multicolumn{2}{|c|}{ Pre fieldwork } & \multicolumn{2}{|c|}{ Post fieldwork } & \multirow{2}{*}{$\begin{array}{l}\text { Significance } \\
\text { (2-tailed) }\end{array}$} \\
\hline & Mean & $\mathrm{SD}$ & Mean & $\mathrm{SD}$ & \\
\hline $\begin{array}{c}\text { Headmaster/teacher/school staff have participated in } \\
\text { trainning/seminar/workshop/conference/discussion relate to disaster } \\
\text { preparedness }\end{array}$ & 0.65 & 0.96 & 1.23 & 0.70 & 0.08 \\
\hline School has media and materials relate to disaster preparedness & 0.51 & 0.91 & 1.63 & 0.73 & 0.00 \\
\hline $\begin{array}{l}\text { The preparedness material has been included in the school } \\
\text { subject which relevant }\end{array}$ & 0.44 & 0.87 & 1.14 & 0.79 & 0.00 \\
\hline $\begin{array}{l}\begin{array}{l}\text { Simulation for disaster' emergency response in school community } \\
\text { have been conducted }\end{array} \\
\end{array}$ & 0.47 & 0.83 & 1.14 & 0.72 & 0.01 \\
\hline Disaster group has material/tools to runs its role & 0.44 & 0.93 & 1.00 & 0.86 & 0.25 \\
\hline Disaster group have been increasing its disaster' knowledge and skills & 0.49 & 0.95 & 1.12 & 0.82 & 0.36 \\
\hline
\end{tabular}




\section{Resources mobilization}

In the resources mobilization (Table 5), there were three items where sig values $>0,5$ they were the participation in disaster-related seminar/workshop, materials/tools for disaster group and simulation for disaster emergency response. Other items showed significantly increase. Through this fieldwork and research, students gained striking improvement of understanding about whether school had media and materials to bring about disaster for the school member. Furthermore, the fact that preparedness materials were integrated to the school subject was known by the students because of their observation and interview in the targeted school. As followed that school conducted disaster simulation and school members have participated in disaster-related courses. The fact that both physical and cultural science about disaster was necessary [23], students needed to acquire their recognition of schools' resources mobilization.

Pre fieldwork questionnaire was filled out by the students before they experienced fieldwork and never been at school to ask for permission or conducting preliminary observation about school conditions. The average of pre-fieldwork mean score 0.66 described that almost every student did not know how disaster risk reduction was held in the school community. Post fieldwork questionnaire was given after students finished their field activities. The increase was found in post fieldwork mean value by 1.46. These scores indicated that students after fieldwork and research knew how school to deal with disaster risk reduction. All in all, it was revealed that there were significant differences for 20 of 36 items, it was indicated that fieldwork and research enhanced students understanding of disaster risk reduction in the school community. From those four parameters there were no one of them was fully recognized by the students, the majority by $50 \%$ of each parameter.

\section{Discussion}

The schools hold several functions in disaster occurrences which being evacuation shelter, an education center for disaster participants and source of disaster information [24]. The idea of creating disaster risk reduction established in the school community gain popularity recently especially on the schools' role in disaster risk reduction [25]. The striking increase in natural disasters created popularity among society[26][27]. One of the most vulnerable areas in Indonesia was Klaten Regency Central Java. As a reaction to some natural disaster that happened created numerous loss, the government had several efforts to reduce disaster risk among society. One of them was school-based disaster risk reduction. The Klaten regency' government released the regent regulation about integrating disaster risk reduction into schools' curriculum. It indicated that school teachers should advance their capability in disaster-related knowledge and skills. As preservice teachers, they should improve students' disaster-related capability in undergraduate geography education [27]. One of the efforts to actualize this method was conducting activity through fieldwork and research in higher education.

The main research question is whether combining fieldwork and research effectively improvescx students' understanding of disaster risk reduction in the school community. Combining fieldwork and research has long been part of the curriculum. It was said that there were four conditions to make fieldwork become powerful teaching strategy. It is very important fieldwork need to be integrated on curriculum level [8]. Furthermore, fieldwork should do systematically by specifying learning outcomes [28]. Geography preservice teacher need to gain knowledge and ability in the disaster management field because integrating disaster-related component into any classroom situation becomes much more essential regarding both natural and man-made disaster [29]. Pre-fieldwork finding showed the variation of students' answers where majoritywas "don't know" which meant that they had no idea about the disaster risk reduction in the school community. Post fieldwork' revealed students' answers were varied. There was increasing value weather it "yes" or "no". From the significant increase, it can be concluded that fieldwork and research bring a positive perception of the student, as the previous research claimed that students own positive views and advantages of fieldwork [30][31][32][33]. However, others found that the attitude and disposition of the students were varied [2]. The positive effect not only lay in the cognitive aspects but also in social aspects as found by Dunphy and Spellman (2009) and Fuller et al, (2006). Other research found affective domain' improvement [32]. Fieldwork support real-world experience for student, skills improvement, and as mention before in social advantages [17]. The significant increasing pretest to posttest indicates that fieldwork and research create a suitable learning environment for the students. The conclusion that students employed better understanding of research methodologies is similar to Fuller, et al, (2014). Fieldwork gained student interest and improved subject-related knowledge and supported active learning [6]. Furthermore, it provided circumstances where students could work effectively in a peer group and staff, increasing the ability to observe and find field methods and data [1].

Students' participation in disaster practice can enhance students' geographical capability as well as developing resilience among society [34]. Moreover, arranged fieldwork provided several learning advantages such as showed different perspectives about landscape, enhancing the ability to gather data from remote locations, and advancing students' skills to collect data [35]. The result showed that the need to enhance the quality of fieldwork in the undergraduate geography eduation curriculum was necessary in order to administer a qualified geography 
teacher [30]. Because of the increasing number of natural disaster events such as earthquakes, tsunamis, and water-related disasters, it was important to reduce the disaster risks and loss in affected areas not only the government but also communities [36]. Education played an essential role in disaster-prone areas in order to advance resilience. Thus the statement should be followed by a suitable knowledge and practice through direct learning. Furthermore the link between school and formal education was significant in the achievement of disaster education [37]. The way to develop preservice teacher program has become the main interest for several decades [38]. Some issues in $\mathrm{x}$ preparation of geography were how to improve teachers' content knowledge and professionalism [39]. By using the advantages of fieldwork and research, preservice teacher can improve their understanding of disaster risk reduction among school communities. However further study needs to be conducted to find the most suitable fieldwork design in disaster areas.

\section{Conclusion}

Combining fieldwork and research supported the improvement in students' knowledge of disaster risk reduction especially for school community preparedness. This method provides real-world experience and students can learn from the actual resources. Comparing the distribution of significant score value of pre fieldwork and post fieldwork questionnaires by 20 of 36 elements, it can be concluded that fieldwork and research increased students' understanding. The understanding was shown in all four parameters, however not all the elements were satisfying improve. It still needed a sustainable effort to raise students' capability in understanding disaster risk reduction in the school community.

\section{REFERENCES}

[1] Trevor J. B. Dummer., Ian G, Cook., Parker, Sara, L., Giles A, Barret, and Andrew P, Hull (2008). Promoting and Assessing 'Deep Learning' in Geography Fieldwork: An Evaluation of Reflective Filed Diaries. Journal of Geography in Higher Education. Vo. 32, No. 3. 459-479.

[2] Dunphy, Alison, and Spellman, Greg (2009). Geography Fieldwork, Fieldwork Value, and Learning Styles. International Research in Geographical and Environmental Education. Vol. 18, No. 1 19-28.

[3] Derek France \& Martin Haigh (2018): Fieldwork@40: fieldwork in geography higher education, Journal of Geography in Higher Education, DOI: $10.1080 / 03098265.2018 .1515187$

[4] Dummer, Trevor. J. B., Cook, Ian G., Parker, Sara L., Barret, Giles A and Hull, Andrew P. 2008. Promoting and Assening 'Deep Learning' in Geography Fieldwork: An Evaluation of
Reflective Field Diaries. Journal of Geography in Higher Education. Vol. 32, No. 3, 459-479.

[5] Elin Charles-Edwards, Martin Bell \& Jonathan Corcoran (2014). Integrating Undergraduate Fieldwork into the Study of Human Mobility. Australian Geographer, 45:4, 505-519, DOI: $10.1080 / 00049182.2014 .953734$

[6] Hope, Max (2009). The Importance of Direct Experience: A Philosophical Defence of Fieldwork in Human Geography. Journal of Geography in Higher Education. Vol. 33 No. 2. 168-182.

[7] Martin Kent, David D. Gilbertson \& Chris O. Hunt (1997) Fieldwork in geography teaching: A critical review of the literature and approaches, Journal of Geography in Higher Education, 21:3, 313-332, DOI: 10.1080/030982697087254 39

[8] Oost, Katie., De Vries, Bregje., and Van Der Schee, Joop A. (2011). Enquiry-driven Fieldwork as a Rich and Powerfull Teaching-Strategy-School Practices in Secondary Geography Education in the Netherlands. International Research in Geographical and Environmental Education. Vol. 20, No. 4, 309-325.

[9] Glenda P. Wall \& Janet Speake (2012) European Geography Higher Education Fieldwork and the Skills Agenda, Journal of Geography in Higher Education, 36:3, 421-435, DOI: $10.1080 / 03098265.2011 .641110$

[10] Ian, Scoot., Ian, Fuller., And Steve, Gaskin. 2006. Life Without Fieldwork: Some Lecturers' Perceptions of Geography and Environmental Science Fieldwork. Journal in Higher Education, Vol. 30, No.1, 161-171.

[11] Tiani Moolman \& Ronnie Donaldson (2016): Career paths of geography graduates, South African Geographical Journal, DOI: $10.1080 / 03736245.2016 .1231625$

[12] R. Gerber and G.K. Chuan (eds). Fieldwork in Geography: Reflection, Perspective and Action, 3-12.

[13] Emma L. Peasland, Dominic C. Henri, Lesley J. Morrell \& Graham W. Scott (2019): The influence of fieldwork design on student perceptions of skills development during field courses. International Journal of Science Education, DOI: $10.1080 / 09500693.2019 .1679906$

[14] Theo Schilderman (2004) Adapting traditional shelter for disaster mitigation and reconstruction: experiences with community-based approaches, Building Research \& Information, 32:5, 414-426, DOI: 10.1080/0961321042000 250979

[15] Fuller, ian., Edmonson, Sally., France, Derek., Higgitt, David, and Ratinen, Ilkka (2006). International Perspective on the Effectiveness of Geography Fieldwork for Learning. Journal of Geography in Higher Education. Vo. 30, No.1, 89-101.

[16] Desai, V. and Potter, R. (eds.) (2006) Doing Development Research. London: Sage Publications.

[17] Fuller, Ian C. Antony Mellor \& Jane A. Entwistle (2014) Combining research-based student fieldwork with staff research to reinforce teaching and learning, Journal of Geography in Higher Education, 38:3, 383-400, DOI: 10.1080/03098265.2014.933403

[18] Triyono. 2013. Handbook of School-Based Disaster 
Preparedness. Jakarta: Indonesia Institute of Sciences.

[19] Yasuo Tanaka (2012) Disaster Policy and Education Changes over 15 Years in Japan, Journal of Comparative Policy Analysis: Research and Practice, 14:3, 245-253, DOI: $10.1080 / 13876988.2012 .687623$

[20] Fatih Demiroz \& Thomas W. Haase (2018): The concept of resilience: a bibliometric analysis of the emergency and disaster management literature, Local Government Studies, DOI: $10.1080 / 03003930.2018 .1541796$

[21] William L. Waugh Jr. (2017): Liza Ireni Saban: Disaster Emergency Management: The Emergence of Professional Help Services for Victims of Natural Disasters (Albany: SUNY University Press, 2014)., Democracy and Security, DOI: $10.1080 / 17419166.2016 .1271099$

[22] Gangalal Tuladhar, Ryuichi Yatabe, Ranjan Kumar Dahal \& Netra Prakash Bhandary (2014) Knowledge of disaster risk reduction among school students in Nepal, Geomatics, Natural Hazards and Risk, 5:3, 190-207, DOI: 10.1080/19475705.2013.809556

[23] Jessica Mercer, J. C. Gaillard, Katherine Crowley, Rachel Shannon, Bob Alexander, Simon Day \& Julia Becker (2012) Culture and disaster risk reduction: Lessons and opportunities, Environmental Hazards, 11:2, 74-95, DOI: 10.1080/17477891.2011.609876

[24] Kenzo Takahashi, Mitsuya Kodama, Ernesto R. Gregorio Jr., Sachi Tomokawa, Takashi Asakura, Jitra Waikagul \& Jun Kobayashi (2015) School Health: an essential strategy in promoting community resilience and preparedness for natural disasters, Global Health Action, 8:1, 29106, DOI: 10.3402/gha.v8.29106

[25] Tong Thi \& Rajib Shaw (2016): School-based disaster risk reduction education in primary schools in Da Nang City, Central Vietnam, Environmental Hazards, DOI: 10.1080/17477891.2016.1213492

[26] Udayangani Kulatunga (2010) Impact of Culture towards Disaster Risk Reduction, International Journal of Strategic Property Management, 14:4, 304-313

[27] Leif Mönter \& Karl-Heinz Otto (2017): The concept of disasters in Geography Education, Journal of Geography in Higher Education, DOI: 10.1080/03098265.2017.1339266

[28] Y1lmaz Ar1 (2019): Fieldwork in geography undergraduate degree programmes of Turkish Universities: status, challenges and prospects, Journal of Geography in Higher Education, DOI: 10.1080/03098265.2019.1698016

[29] Sven Fuhrmann, Lee D. Stone, Melinda C. Casey, Mary D. Curtis, Amber L. Doyle, Brian D. Earle, Douglas D. Jones, Philip Rodriguez \& Steven M. Schermerhorn (2008) Teaching Disaster Preparedness in Geographic Education, Journal of Geography, 107:3, 112-120, DOI: $10.1080 / 00221340802458482$

[30] Sladana Andelkovic, Vojislav Dedjanski \& Biljana Pejic (2017): Pedagogical benefits of fieldwork of the students at the Faculty of Geography in the light of the Bologna
Process, Journal of Geography in Higher Education, DOI: 10.1080/03098265.2017.1379058

[31] Stokes, Trevor Collins, John Maskall, John Lea, Paul Lunt \& Sarah Davies (2012) Enabling Remote Access to Fieldwork: Gaining Insight into the Pedagogic Effectiveness of 'Direct' and 'Remote' Field Activities, Journal of Geography in Higher Education, 36:2, 197-222, DOI: $10.1080 / 03098265.2011 .619004$

[32] Alan Boyle, Sarah Maguire, Adrian Martin, Clare Milsom, Rhu Nash, Steve Rawlinson, Andrew Turner, Sheena Wurthmann \& Stacey Conchie (2007) Fieldwork is Good: the Student Perception and the Affective Domain, Journal of Geography in Higher Education, 31:2, 299-317, DOI: $10.1080 / 03098260601063628$

[33] Fuller, Ian Steve Gaskin \& Ian Scott (2003) Student Perceptions of Geography and Environmental Science Fieldwork in the Light of Restricted Access to the Field, Caused by Foot and Mouth Disease in the UK in 2001, Journal of Geography in Higher Education, 27:1, 79-102, DOI: $10.1080 / 0309826032000062487$

[34] Elyse Zavar \& Mary Nelan (2020): Disaster drills as experiential learning opportunities for geographic education, Journal of Geography in Higher Education, DOI: $10.1080 / 03098265.2020 .1771684$

[35] Anthony D. Cliffe (2019): Evaluating the introduction of unmanned Aerial Vehicles for teaching and learning in geoscience fieldwork education, Journal of Geography in Higher Education, DOI: 10.1080/03098265.2019.1655718

[36] Koichi Shiwaku, Rajib Shaw, Ram Chandra Kandel, Surya Narayan Shrestha, Amod Mani Dixit, (2007) "Future perspective of school disaster education in Nepal", Disaster Prevention and Management: An International Journal, Vol. 16 Issue: 4, pp.576-587, https://doi.org/10.1108/096535607 10817057

[37] Nurdin N., Rafliana I., Hidayati S., Oktari R.S., Djalante R. (2017) Integrating Disaster Risk Reduction and Climate Change Adaptation into School Curricula: From National Policy to Local Implementation. In: Djalante R., Garschagen M., Thomalla F., Shaw R. (eds) Disaster Risk Reduction in Indonesia. Disaster Risk Reduction (Methods, Approaches, and Practices). Springer, Cham

[38] Jerry T. Mitchell (2017): Pre-service teachers learn to teach geography: a suggested course model, Journal of Geography in Higher Education, DOI: 10.1080/03098265.2017.139871 9

[39] Kathrin Viehrig, Daniel Siegenthaler, Samuel Burri, Sibylle Reinfried, Sarah Bednarz, Marian Blankman, Terri Bourke, Clare Brooks, Philippe Hertig, Joseph Kerski, Thomas Kisser, Michael Solem, Joseph Stoltman, Yvonne Behnke, Rod Lane, Marco Lupatini, Nina Scholten, Alexander Siegmund \& Sandra Sprenger (2019) Issues in improving geography and earth science teacher education: results of the \#IPGESTE 2016 conference, Journal of Geography in Higher Education, 43:3, 299-322, DOI: 10.1080/03098265.2019.1608920 